\title{
FOSTERING CRITICAL THINKING SKILLS THROUGH ARGUMENTATIVE WRITING
}

\author{
Susana Widyastuti \\ Fakultas Bahasa dan Seni, Universitas Negeri Yogyakarta \\ email: susana_widyastuti@uny.ac.id
}

\begin{abstract}
The urgency for developing students' critical thinking (CT) abilities has left English as a Foreign Language (EFL) teachers trying hard to integrate CT into their teaching practices.This study highlights the role of language as a way of thinking, judging and assessing.It seeks to investigate how the elements of CT are displayed in students' essay so as to reveal the development of their CT skills. The data are in the form of essay written by the fourth semester Indonesian students taking essay writing course.Theanalysis is based on Stapleton's criteria of CT(2001), i.e. claims, kinds of reasoning, the extent of evidence, recognition of opposing arguments and refutation, and fallacies. The results show that there are many weak arguments in the essays due to the insufficiency of reasons and evidence. It is highly possible for an essay to have multiple arguments. However, the logical correlations between them are not clearly articulated in the essays and many students fail to show them. Students also lack of refutation skills as they tend to accept a claim from other sources without trying to judge and evaluate it. While most conclusions are in the form of suggestion, they can be made better by clearly showing the position of the writer in relation the arguments posed in the essay. Fallacies are mostly found in the form of generalization and over-simplification. The results are expected to give insights to teachers about how CT skills could be effectively taught and improved in writing classes.
\end{abstract}

Key words: argumentative writing, critical thinking (CT), English as a Foreign Language (EFL)

\section{MENGEMBANGKAN KEMAMPUAN BERPIKIR KRITIS MELALUI MENULIS ARGUMENTATIF}

\begin{abstract}
Abstrak: Pentingnya mengembangkan kemampuan berpikir kritis (critical thinking atau CT) mahasiswa telah membuat para pengajar English as a Foreign Language (EFL) berusaha keras mengintegrasikan kemampuan berpikir kritis dalam pengajaran mereka. Penelitian ini menggaris bawahi peran bahasa sebagai sarana berpikir, menilai, dan mengevaluasi. Penelitian bertujuan untuk menggali bagaimana elemen-elemen berpikir kritis ditunjukkan dalam teks dan mengkaji perkembangan berpikir kritis dalam teks. Data berbentuk teks essay yang ditulis oleh mahasiswa semester 4 yang mengambil matakuliah Essay Writing. Data dianalisis berdasarkan kriteria Critical Thinking (CT) oleh Stapleton (2001), yaitu argument, reason, evidence, opposition and refutation, conclusion, dan fallacy. Hasil penelitian menunjukkan bahwa argumen sering lemah karena tidak didukung oleh alasan dan bukti yang cukup. Suatu esai sangatlah mungkin mengandung banyak argumen. Namun demikian, hubungan logis antar argumen tersebut tidak jelas dalam esai dan bahkan banyak mahasiswa gagal menunjukkan hubungan tersebut. Mahasiswa juga lemah dalam hal refutation skill karena mereka cenderung menerima klaim dari sumber lain begitu saja tanpa mencoba mengevaluasi dan mempertanyakannya. Kebanyakan kesimpulan berbentuk saran dan bisa dibuat lebih baik dengan menyatakan dengan jelas posisi penulis dalam menanggapi argumen-argumen yang dikemukakan di awal. Fallacy kebanyakan dalam bentuk generalisasi dan penyederhanaan berlebihan. Hasil penelitian ini diharapkan dapat memberikan masukan tentang bagaimana kelas menulis dapat dirancang secara efektif supaya dapat menumbuhkan baik kemampuan berpikir kritis maupun kemampuan berbahasa.
\end{abstract}

Kata kunci: tulisan argumentatif, berpikir kritis, English as Foreign Language (EFL)

\section{INTRODUCTION}

This study seeks to foreground the interconnections between critical thinking (CT) and language. The close correlation between thinking (cognition) and language development has long been recognized by scholars and educators, because it is through language people come to know the world and express what 
they think about. It is particularly relevant for argumentativewriting in the English as a Foreign Language (EFL) context, because to make an argumentative writing people need to have both higher-order thinking skills and higher levels offoreign language proficiency (see Atkinson, 1997; Chamot, 1995; Tarvin\& Al-Arishi, 1991).

Critical thinking (CT) has been widely considered as an essential skill in the twentieth century particularly in the area of language education. Although $\mathrm{CT}$ itself is a complex concept and is not easy to define, it is an identifiable thinking skill and thus can be practiced. Facionedefines critical thinking as "purposeful, self-regulatory judgment that results in interpretation, analysis, evaluation, and inference, as well as explanation of the evidential, conceptual, methodological, criteriological, or contextual considerations upon which that judgment is based" (1990, p. 3).

Beyer defines it as the ability to make "reasoned judgments" (1995, p. 8). Critical thinkers thus should be able to judge, evaluate, and question an idea or thought based onreliable evidence by establishing logical relationships among statements or data. Such ability is crucial in developing language competence especially in constructing arguments and inferring a conclusion from one or multiple premises.

Premised on the intertwined correlations between $\mathrm{CT}$ and language and the aspects of CT abilities proposed by scholars (see Facione, 1990 and Beyer, 1995), this study focuses on 'developing CT through and in writing'. The development of critical thinking skills of EFL learners through writing has not gained much attention, although there have been numerous research on critical thinking skills. This study particularly takes into account argumentative writing, a type of writing which requires high thinking skills and is thus believed effective to improve students' CT (see Langer \& Applebee, 1987).

A writing course which stimulates students to engage in critical thinking is believed more effective than traditional methods of writing. The integration of CT into argumentative writing can be premised on the tenets that, firstly, CT is an integral part of argumentative writing, in combination with other important language aspects of writing. To write is to argue and to argue is to think. Argumentative writing thus requires a complex skill involving not only practical but also cognitive and social aspects and thus requires students to have sufficient background knowledge about the issue being written about.

Secondly, writing can significantly help students develop both their CT skills and language competence. Writing is the verbal manifestation of CT. Critical thinkers need to master multiple writing skills and abilities, i.e. to analyze facts, generate and organize ideas, defend opinions, make comparisons, draw inferences, evaluate arguments and solve problems (Chance, 1986, p.6).

Stapleton (2001) highlights the strong correlations between thinking and writing. A thinking mind should be reflected in writing. Stapleton (2001,pp. 536-539) proposes sixcritical thinking elements ina written text.

a. Arguments: claims which are supported by a reason. In academic writing, an argument is usually a main idea, often called a "claim" or "thesis statement".

b. Reasons: statements which are used to support claims and generally answer why the claim should be believed.

c. Evidence: statements or assertions serving to strengthen the argument.

d. Recognition of Opposition and Refutation: Opposing viewpoints that run counter or offer alternative interpretations to those expressed in the claim.

e. Conclusion: a statement or series of statements in which a writer sets out what she wants the reader to believe.

f. Fallacies: errors in reasoning.

The outline of the essay writing course that becomes the setting of the study places CT as an important learning outcome. In doing so, multiple-step writing processesare applied on the basis that the more they write, the more they practice, the more they think. Weekly writing tasksare used to easily trace and identify the progress. The steps basically involve the planning, writing, and revising. While the main writing process itself is not unimportant, the planning (researching, brainstorming, and outlining) and post-writing (feedback and revision) are crucial for improving writing performance and CT.

This study particularly highlights the need for (1) the planning or pre-writing stage which 
allows students do enough reading, research and exploration on the issue being assigned and plan their writing (brainstorming and outlining) and (2) continuous feedback from the lecturer to allow them do self-reflection and revise their texts. This is to say that comprehending the concept they need to write and evaluating/revising their own writingare crucial for sharpening their CT skills.

Closely related to the writing steps, topic isan important aspect that determines the goal, nature and structure of writing. Thus the topic chosen in this study is the one that can stimulate students' argumentative skills. The topic is carefully selected by considering the CT elements, as students need to have something to think critically about, and the language aspect, as students at the same time need to learn how to use various language resources to construct their arguments. By doing so, students are able to develop their English language skills while simultaneously becoming more knowledgeable about the issues in the world they live in.

\section{METHODS}

The setting of the study is an essay writing course taken by the $4^{\text {th }}$ semester students of the English literature study program. The language of instruction is English and all of the students are Indonesians. Their English language levels and abilities vary and they frequently lack of confidence. This situation is similarly described in a study by Tsui (1996) which also reveals that the cause is the lack of opportunities and willingness to use English in everyday context.

The data were the collection of students' argumentative essays. The course ran for 16 weeks which were used mostly for writing practices. Each week students attended 2 classes which ran for 100 minutes each. In the second class students wrote independently based on the topic assigned to them. The teaching method was generally communicative and learnercentered, in which lecturer talked to students intensively to discuss and give feedback to their writing. Such method was intended to stimulate students' writing productivity and improve their confidence in writing, both in the content and language aspects. The feedback and evaluation focused on the writing progress by paying attention to each $\mathrm{CT}$ element.
At the first two weeks the classes were focused on the 'the what' and 'the how' an argumentative essay could be written. It included the nature, types, content, structure and language of an essay. It was found from the discussion that students particularly did not have enough understanding about the critical nature of an essay they needed to produce during the course and about the language expressions that could help construct their critical arguments.

The tasks were broken down weekly into a series of stages using various topics, to allow students learn specific CT skills or elements suggested by Stapleton (2001). The writing process was done systematically. Students were given instructions and given time to brainstorm and develop their outlines, given opportunities to do peer-review and given feedback on the process. This was surely time-consuming, yet the intention was to maximize the quality of students' writing.

Various topics about social life were selected on the basis that they could stimulate and elicit students' personal and intellectual arguments as well as sharpen their awareness to current social phenomena. The topics would need students to collect enough information and to decide what kind of arguments they would construct, including problem solving, cause and effect, decision making, social criticism. For the final assignment, students were particularly asked to write about 2019 presidential election in Indonesia. Studentswere allowed to develop or break down the topic into more specific subtopics they were most interested in.

The process of analysis was done through a close look at each essay. Each element was identitified and the key clauses indicating the CT element was highlighted. To achieve validity, each essay was examined by two raters.

\section{RESULTS}

The discussion that follows focuses not only on how each element is displayed but also on how the linguistic choices are effective to show each element. However, it is necessary to note that the data may contain grammatical mistakes.

Table 1 shows the distribution of each CT element in 30 essays.

1. Arguments 
Table 1. CT elements in students' essays

\begin{tabular}{lcccccc}
\hline & argument & reason & evidence & Opposition and refutation & conclusion & fallacies \\
\hline Rater 1 & 138 & 69 & 57 & 25 & 29 & 11 \\
Rater 2 & 128 & 82 & 56 & 18 & 30 & 8 \\
\hline
\end{tabular}

Feldman (1998) argues that a good argument should be purposeful, clear, and concise. The results indicate that crafting an argument isa challenge for the students. There are two interesting phenomena that can be learnt from students' essays. Firstly, most opening sentences in the essays are used to pose a problem, that is the main argument. However, not all of them are directly followed by definitionor clarification of what they mean in the argument. If the definition is present, it mostly uses simple present tense. Modal auxiliary such as "may", "might" and verbs like "suggest", "show" "demonstrate" "indicate" are not used often.

\section{Extract 1}

Press or social media has a very important role in the life of a nation. Press plays an important role in the process of creating the character of society and developing national insight. Besides, press is an important component in the process of mass communication. According to JalaludinRachmad: mass media is the medium used for chanelling communications to the public such as the press, radio, television, movies and so on. As a means of communication for dissemination information and ideas to the public, the mass media has an important role in human life in various fields, such as political, economic, social, and cultural fields, etc (JalaludinRakhmat, 1990: 135) (Student A).

In this opening paragraph (extract 1), A writes an argument repeatedly in the first three sentences to show his standing on the importance of the press. In the fourth sentence, he provides the definition of the proposed claim using a quotation in the form of present tense sentence cited from an expert in the area. By doing so, thereaders are being orientated to the point that the rest of the text would tell about to what extent the press is important, particularly in the areas suggested in the last two lines. This is to say that the whole text would be merely explanatory and descriptive and thus less critical in nature.

Secondly, one student usually has multiple arguments in one essay (138 arguments in 30 essays). However, they are rarely well-connected.
Sub-arguments do not support the main argument stated earlier in the first paragraph. Conjunctions showing inter-clause relationship are not used often. In a nutshell, there are times when students write various arguments which seem connected but they fail to show the relationship between them.

Looking at the details, the paragraphs in A's writing are dominated by description of the press (1 paragraph), the history the Indonesian press ( 1 paragraph) and the rest ( 7 paragraphs) is all about the freedom of speech as part of the functions of the press as a political vehicle, completed with definition and examples. The argument constructed in the first paragraphthus should specifically about the political role of the press or the freedom of speech in politics. Having said this, the main argument is not well represented throughout the text.

\section{Extract 2}

The Indonesian electionday is coming with more figures and political parties nominated in the candidate list. With that in mind, it is necessary for all active voters to make themselves prepared by being more critical to political issues and candidates they are about to vote. An attempt to think critical about politic might help citizens to build a wiser way of thinking responding to the complicated political condition in Indonesia. Following the critical attitude toward political issue, open minded voters might be more considerate about their vote as to avoid random vote and political party domination in a particular society(student B).

In B's first paragraph (extract 2), the main argument is well constructed in the first two sentences. While the first sentence is more general and provides the context of the main argument, that is about the growing number of political figures and parties, the second is an argument in the form of suggestion, with a conjunction'with that in mind', about how to deal with such political phenomenon. This argument shows the writer's standing about being critical voters. The use of several adjectives in the paragraph strengthens the force of the main argument. In 
the last two sentences in extract 2 the writer addresses briefly about being a wise and openminded voter. The readers are orientated that the rest of the text would be about the qualities of a critical voter.

\section{Reasons}

Supporting reasons are indispensable to an argument. In other words, a claim can not stand alone withouta convincing reason. Otherwise, it is called an opinion. Critical thinkers should provide the 'why' aspect of the proposed argument (seeCrosswhite, 2012) in order to make people convinced and believe in what we have claimed in the argument.A well-written reason can help readers understand and accept the writer's position.

Langer \& Applebee (1987) suggest that "the greatest variety of reasoning operations occur during essay writing, suggesting that this type of activity provides time for students to think most flexibly as they develop their ideas" (p. 100). Through essay writing students have the opportunities to develop arguments based on the interconnections between many claims from various resources.

The reasons need to show a direct logical relationship with the argument. A's paragraph (extract 1) mostly argues that the Indonesian press has been used widely as a political means. However, he does not provide any logical reason why this takes place within the context of Indonesia. The majority of the paragraphs explain the topic by providing definition (by quoting some sources), history and examples. Thus A's text lacks of the quality of an argument.

B's argument (extract 2 sentence 2) is directly followed by two sentences indicating the reasons. They do not use such conjunctions like 'because' and 'for', yet the clauses indicate relationships that answer the question 'why'. The next paragraphs also contain some reasons supporting his argument.

In general, students display weak reasoning skills. If the reasons present, the students fail to show the logical relationship between the argument and reasons. Conjunctions indicating cause and effect relationship are helpful, but they are rarely used. Therefore, the readers are left wondering about the relationship between many unorganized claims in their essay.
The findings show that there are a huge number of arguments. However, the number of reasons and evience is not as many as that of the arguments. In a nutshell, the arguments are weak due to the lack of supporting reasons and evidence.

Ramage and Bean (1999) state that evidence can be in the form of personal experience, research studies, statistics, citing authorities, comparisons and analogies, pointing out consequences, facts, logical explanations, and defining words. The evidence given by A (extract 1)is in the form of facts. Most of them specifically support the argument about the political role of media. They are not in line with the main argument in the first paragraph.

Extract 3

For example is TvOne which is led by Ardi Bakrie, the son of the general chairman of party Golkar, Aburizal Bakrie (student A)

\section{Extract 4}

The example of the case is the president election in 2004 (student A)

Research studies and statistics are rarely used although such data are available in many online and printed sources. This shows that students do not do intensive research through such existing resources prior to the writing process.

\section{Opposition and refutation}

The descriptive nature of most students' texts indicates the lack of abilities to counterthe argument at hand. They hardly have the sense of "judging" and "questioning" (see Beyer, 1995). On the other hand they just copy information from other sources without any evaluation.

The lack of evaluation is indicated through the less use of adjectives as well as subjective judgments. Extract 1 shows that rather than writing a critical thesis statement in the introductory paragraph, the writer makes mere descriptive claims by giving definition and examples of the press, i.e. radio, television, and movies and the areas that may be affected by the press. The argument is not effective either due to the repetition of the same word 'important role' four times in the same paragraph.

\section{Evidence}


As indicated in the first paragraph, it is not surprising that A displays a low refutation skill. A's argument in extract 1 contain a strong and concise message. However, in the following sentences the writer does not propose any potential conflict in relation to the claim. Instead of questioning the validity of ideas in texts or judge the ideas of other people, A's text contains a lot of definition taken from various sources.

Refutation is considered as the weakest element in students' texts. It can hardly be seen that students are able to filter knowledge of all sorts through their reasoning and to find logical flaws instead of accepting them as they are. The so-called 'healthy skepticism' (Lipman, 1991), requires students to possesreasonable and reflective thinking before deciding what to believe and do. However, the data show that students need to improve their ability to present logical linkage between different (opposing) views.

\section{Conclusions}

Conclusion should restate and reconfirm the writer's position and show the correlations between all the CT elements in the given essay (see Halpern, 2013). Most importantly it should contain the writer's critical point of view about the earlier claims in the essay.

\section{Extract 5}

The press should not be used as a political device, but as a device that gives information to the public in order to make them receive a good political education and to know the development of the nation (student A)

A's conclusion is clear and indicates his standing that, through the use of 'should not' he strongly disagrees with the employment of the press for political purpose. He also inserts a concluding personal statement suggesting the better way of using the press. The conclusion reconfirms the arguments stated earlier. Nevertheless, the focus is more specific than the main argument stated in the first paragraph (see my earlier explanation on argument). B's conclusion is also in the form of suggestion in relation to the earlier arguments (extract 6).

Most essays have conclusions, which usually contain suggestion. However, not all of them use explicit expressions like 'in conclusion' as used in extract 6 . In most cases, the readers are left wondering about the interconnection between all the arguments proposed by the writer and, thus, have to figure out the relevance of the concluding sentence in the last paragraph.

\section{Extract 6}

That way, we will not be easily framed to a certain way of thinking by individuals who want to steal our right to vote in freedom. We have to stand in our own perspective and assumption to maintain the principle of election in Indonesia. In conclusion, we have to be more critical and more concerned about political condition in Indonesia. As an eligible voter, our vote will contribute to the future of Indonesia, so we have to use it with responsibility and full consciousness (student B).

\section{Fallacies}

Defined as flaws of reasoning, fallacies detract the overall value of an argument. Thinking critically means finding logical fallacies, the situation when the reason does not adequately support the claim in a number of ways.

The fallacies found in this study show that not all arguments are valid or even logical. This is in line with the findings on the refutation skill discussed earlier suggesting that students do not put enough efforts to always critically think and examine the argument they confront.

The main types of fallacies found in the essays are generalization and over-simplification. The writer tends to undermine the complexity in an argument. The main cause of fallacies found in this study is the insufficient evidence to support the argument.

\section{Extract 7}

It suggests that social media is dangerous for guiding people's assumption and that is way the politics in Indonesia is always controlled by certain people (student $\mathrm{C}$ ).

In extract 7 the writer generalizes the idea of the danger of social media, and, at the same time, switches the discussion away from social media to the Indonesian politics which is not directly related to the first claim. The writer over-simplifies the claim although it contains a complex argument. The absence of evidence of the danger of social media weakens the 
argument and makes the readers wonder about the relationship between the two clauses.

\section{DISCUSSION}

It is particularly interesting thatparticipants might come to the classrooms with presumably low critical thinking skills, yet they understand that the essay they write are supposed to be argumentative. They are expected to understand and apply the major tenets of argumentation as a type of writing which requires high critical thinking (see Rottenberg, 1991).

The data provide fruitful insights into understanding students' CT abilities. Firstly, apart fromthe absence of certain elements in some essays, some students are not able to show the correlations among CT elements. The elements should be mutually informing, yet students fail to show their interconnection in the essay. This can be due to students' lack of linguistic competence, particularly in the use of conjunctions. While it is highly possible for a text to have multiple arguments, they have to support each other and construct the main argument postulated in the first paragraph. Irrelevant or absent conclusions are part of this inability. Thus, a critical thinker should be able to generate logical correlations among various elements. To draw logical relations needs students to do critical reflection in a way they have to be able to construct their own ideas and develop sound standards for analyzing and assessing them.

Secondly, while students are encouraged to think critically, they seem to be prone to receive any information without questioning. They tend to transfer the sentences from the sources to their essay without any attempt to evaluate and digest them. This is to say that the essay has not gone through a critical thinking process. As suggested in the low result of refutation skills discussed earlier, questioning a claim seems an unacceptable attitude in the existing traditional writing course.

Thirdly, the insufficient reasons and evidence to support an argument may indicate the lack of students' background knowledge on the essay topic. Topic familiarity becomes an issue here as students are not able to connect the topic to the world and their real life experience. This may also due to students' low reading habits. Further research should focus on the correlations between writing and reading in shaping $\mathrm{CT}$.
Overall, the results highlight that the course needs to be well-designed in order to foster students' skills in displaying each element in their essay. In this case, firstly, CT and how its elements can be displayed through texts should be clearly stated in the course objectives and students should understand from the very beginning that $\mathrm{CT}$ is part of the learning goals. Secondly, its outline needs to give clear instructions which aim to practice and sharpen each CT element. The learning goals and design should go beyond linguistics aspects and pay bigger attention at the development of students' CT (see Brown, 2004).

\section{CONCLUSIONS}

Since higher-order thinking skills are increasingly required for success in a knowledgebased society, it is crucial to develop CT skills so as to improve students' exposure to the use of English in academic and day to day use and to the world they live in. The study suggests that the integration of CT aspects in EFL argumentative writing has helped the students develop not only their critical thinking skills but also their English language competence. Without adequate practice in critical thinking, EFL students may lack confidence in their academic life and miss the opportunity to advance up the ladder in the global workplace which has become more challenging.

The lack of critical thinking in an EFL writing course as suggested by the results of this study imply that the course design needs to be reconstructed in such a way in order to foster the ability to engage critical thinking. The reconstruction may include the material development and the teaching and learning techniques. The course can be a shift from traditional course, which focuses merely on language skills, to a more integrated and comprehensive course which can simultaneously develop both $\mathrm{CT}$ and language skills.

Focusing on this reconstruction, further research should also take into account on how to improve students' awareness on the importance of background knowledge through reading. Without such knowledge students will not be able to find ways in their writing to make meaningful connections between their writing and their world. The research can also take into account the role of reading for shaping $\mathrm{CT}$ in writing. 
The natural way to improve one's writing is to cultivate the habit of reading for pleasure. Reading can be the most effective, convenient and enjoyable way to better writing.

\section{REFERENCES}

Atkinson, D. 1997. A critical approach to critical thinking in TESOL. TESOL Quarterly, 31, 71-94.

Beyer, B. K. 1985. Critical thinking: What is it? Social Education, 49 (4), 270-276.

Beyer, B. K. 1995. Critical thinking. Bloomington, IN: Phi Delta Kappa Educational Foundation.

Brown, H.D. 2004 . Some practical thoughts about students- sensitive critical pedagogy. The Language Teacher,28(7), 23-27.

Chamot, A. 1995. Creating a community of thinkers in the ESL/EFL classroom. TESOL Matters, 5(5), 1-16.

Crosswhite, J. 2012. The rhetoric of reason: Writing and the attractions of argument. University of Wisconsin Pres.

Davidson, B. 1995. Critical thinking education faces the challenge of Japan. Inquiry: Critical Thinking Across the Disciplines, 14(3), 41-53.

Facione, P. 1990. Critical Thinking: A Statement of Expert Consensus for Purposes of Educational Assessment and Instruction. Research Findings and Recommendations. The Delphi Report." Milbrae, CA: California Academic Press.

Feldman, R. 2013. Reason and Argument: Pearson New International Edition. Pearson Higher Ed.
Halpern, D. F. 2013. Thought and knowledge: An introduction to critical thinking. Psychology Press.

Langer, J.A. \& Applebee, A.A. 1987. How writing shapes thinking: A study of teaching and learning. Urbana, Ill: National Council of Teachers of English.

Lipman, M. 2003. Thinking in education. New York: Cambridge University Press.

Ramage, J. and C. Bean. 1999. Writing Arguments. Allyn and Bacon. Boston

Stapleton, P. 2001. Assessing critical thinking in the writing of Japanese university students: Insights about assumptions and content familiarity. Written Communication, 18(4), 506-548.

Stapleton, P. 2002. Critical thinking in Japanese L2 writing: Rethinking tired constructs. ELT Journal, 56(3), 250-257.

Tarvin, W., \& Al-Arishi, A. 1991. Rethinking communicative language teaching: Reflection and the EFL classroom. TESOL Quarterly, 25(1), 9-27.

Tsui, L. 1999. Courses and instruction affecting critical thinking. Research in Higher Education, 40(2), 185-200.

Tsui, L. 2002. Fostering critical thinking through effective pedagogy. Journal of Higher Education, 73(6), 740-763. 